\title{
Proclaiming East Timor: Historical Reflections on Political Declarations
}

\section{Douglas Kammen}

National University of Singapore

\begin{abstract}
East Timor celebrated its independence in 2002, but behind the euphoria the subject of the celebration was hotly contested. While most foreign observers treated this as the achievement of independence, according to the Constitution and the first government 20 May 2002 marked the restoration of independence that was first proclaimed by Francisco Xavier do Amaral in November 1975. Given the significance that declarations of independence hold, this article traces the history of political declarations in East Timor over the course of three centuries. It examines a curious pair of declarations in 1702-1703, the many declarations of vassalage in the nineteenth century, the declaration of the Portuguese Republic in 1910, the competing political declarations in 1975, and a curious declaration of a breakaway republic in 2005 .
\end{abstract}

Keywords: East Timor; independence; colonialism; monarchy; republic.

On May $20^{\text {th }}$ of 2012, East Timor celebrated its tenth anniversary. The young nation, however, is deeply divided over what it is that was celebrated: some East Timorese argue (and many international observers concur) that this was the tenth anniversary as an independent nation-state, while others insist that independence was proclaimed on 28 November 1975 and that, as stated in the constitution, 20 May 2002 marks the restoration of independence and the achievement of full international recognition. This is not an idle debate, for the positions taken are indicative of a deeper divide between those who support the Parliamentary Majority Alliance, headed by José Alexandre "Xanana" Gusmão, 
and those who identify with the Revolutionary Front for an Independent East Timor (Fretilin), led by Mari Alkatiri and Francisco "Lu Olo" Guterres.

Public debate over declarations of independence is all too common, in part because of popular misunderstandings about the difference between a declaration and the achievement of independence, in part too because of misconceptions about what each represents. It is, therefore, useful to recall that declarations are fundamentally expressions of the nation while the achievement of independence signifies above all else international recognition of statehood. As Pauline Maier writes of the United States - itself no stranger to debates about its own founding - the Declaration of Independence in 1776 was "the promise of a representative government;" the Constitution of 1887 was "the fulfillment of that promise" (Maier back cover). Building on this distinction, this essay reflects on the history of political proclamations in East Timor by examining four declarations spread across three centuries, highlighting issues of language as well as political theory.

\section{Declarations of Vassalage}

The Portuguese first arrived in the Solor and Timor archipelago in the early sixteenth century in search of the sources of sandalwood, but it was not until 1702 that the Viceroy of Goa appointed the first Portuguese governor, with the grandiloquent title "Governor and Captain-General of the islands of Timor and Solor and other regions of the South" (Boxer 183). Upon arrival, Governor António Coelho Guerreiro made the bold decision to move the base of Portuguese operations from Larantuca, on the island of Flores, to the settlement of Lifau, on Timor. His efforts to exert control, however, were challenged almost immediately by the Larantuqueiros (also known as the "Black Portuguese") - the ethnically mixed, Portuguese-speaking and Catholicized community then under the leadership of Domingos da Costa. A three-year siege ensued, during which our first political "declarations" were made. In May 1702, Governor Coelho Guerreiro wrote to the Viceroy of Goa to explain the problems he was encountering. The Larantuqueiros, he wrote,

\footnotetext{
... em que me reprotestauão que herão amigos, e irmãos em armas com

El Rey Nosso Snr negando lhe o homen de vassalos e querendosse conste-
} 
tuir republica imdependente por adjudicando assy a eleição do gouerno e o disporem dos fuitos da ilha ao seu arbitrio, sem que S. Mag. ${ }^{\text {de }}$ tiueçe nellas mais que o nomem do rey por dispençação da sua vontade.... (Matos 235)

... protested that they were friends and brothers in arms of the King Our Lord, denying him the name of vassals, and they wished to constitute an independent republic to decide therewith the election of a government and dispose of the fruits of the island as they wished, without His Majesty having more than the name of king.... (Hägerdal 320)

Had Domingos da Costa really made his case in terms of "an independent republic" and the need for "elections," or is this the Governor's attempt to discredit the rebel leader? The latter seems more likely. For the following year Domingos da Costa sent an equally extraordinary letter to King Pedro II of Portugal, protesting against the atrocities committed by Governor Coelho Guerreiro and describing the mutiny of "gentiles and Christians alike." In the final lines da Costa admitted that he too joined the maquis, but defended this on grounds that he remained loyal to King Pedro II:

... e como os pouuos de Timor uendo que se perdia a ilha mandou chamar ou pouuo de Sollor, e que me trouxesse por força, o que outra uez de nouo me protestarão da parte de Deõs, e d V. Real Mg. ${ }^{e}$ uiesse para Timor, e que de tudo faria prezente a V. Real Mg. é; e uendo eu o protesto delles torney a deitar o posto de Capitão mor assy por me doer muito dos suores do meu Pay Matheus da Costa vertidos nesta ilha como por entender fazer seruiço a V. Real Mg. é; em que espero trará a memoria os merecimentos do meu Pay, como tão bem o despacho destes pouuos vassalos leaes de V. Mg. e os quaes pedem com justiça, e muita rezão serem essas ilhas gouernadas pellos naturaes, por que as defenderão the acabar o sangue de suas ueas.

Deos a V. Real Mg.e guarde para amparo deste Oriente. Teimor em Mayo de 1703.

De Vossa Real Mg. ${ }^{e}$ Minimo Soldado

Domingos da Costa 
... and as the people of Timor, seeing that they were losing the island, called to the people of Solor, and that they took me there forcefully and once again protested on behalf of God, and of your Royal Majesty, that I come to Timor, and that all would be presented to your Royal Majesty, and seeing their protest, I got back to my position as Commander, as it pains me greatly the sweat that my father, Matheus da Costa, poured into this island, as much as with the understanding of my doing service to your Royal Majesty; in this I hope to bring to mind the merits of my father, also the dispatch of the loyal vassal peoples of Your Majesty, who ask with justice and much reason for these islands to be governed by native sons, because they will defend them to their last drop of blood.

God save Your Royal Majesty for protection of this Orient.

Timor on May 5, 1703.

Most humble soldier of Your Royal Majesty

Domingos da Costa (Matos 308-9)

That a Timorese composed this letter in Portuguese in 1703, and did so in full confidence that the letter would reach the King of Portugal on the other side of the world, is altogether remarkable. It is, perhaps, tempting to read da Costa as arguing for the legitimacy of rebellion and for the claim that rebellion may give rise to legitimate forms of rule, much as American revolutionaries argued towards the end of the same century. But that is not the case: da Costa had no access to Enlightenment thought, to Montesquieu or Rousseau, to the Rights of Man or ideas of representative government. Instead, da Costa's argument is that loyalty (that of his father, his own, and the "the people of Timor") to the Portuguese crown must be repaid with just rule (preferably in the person of "native sons").

From the early eighteenth century onward, Portuguese governors cajoled, bribed and at times coerced indigenous rulers, whom they termed Rei or Regulo (Little King), to sign terms of vassalage (termos de vassalagem), swearing fealty to the Portuguese crown and vowing to obey the Governor. In 1769, threatened by the ongoing rebellion of the Black Portuguese under the leadership of the da Costa and Hornay families, Governor Teles de Meneses packed up the 1,200 members of the tiny settlement of Lifau and sailed down the coast to Dili, 
where he was welcomed by the ruler of the Kingdom of Motael and granted permission to establish a new capital. One of Teles de Meneses' first initiatives was to summon more than forty indigenous rulers to sign new terms of vassalage. The practice appears to have waned during the early nineteenth century, during which the Portuguese presence reached a nadir, but by mid-century, as the first real efforts were made to establish a functioning colonial regime, terms of vassalage again became the lynchpin in the expansion of territorial control. These documents, many of which have survived in the colonial archives, were highly formulaic. This one, from 1881 , is typical:

Eu D. Duarte Gutterres, coronel regente do reino de Venilale da parte da rainha do mesmo reino D. Isabel Gutterres, juro aos Santos Evangelhos vassallagem a El-Rei de Portugal o Senhor D. Luiz I, e por preito e homenagem me obrigo a cumprir todas as ordens dos senhores governadores d'esta districto de Timor e a manter e fazer respeitar no meu reino a religião catholica e bem assim a pagar a finta que me for ordenada e dar auxilio para a Guerra e serviçaes para o serviço publico quando me forem requisitados. (Boletim 56)

I, Dom Duarte Gutterres, colonel and regent of the kingdom of Venilale, on behalf of the queen of the same kingdom, Dona Isabel Gutterres, swear in the name of the Holy Gospels vassalage to the King of Portugal, His Majesty D. Luiz I, and through contract and homage vow to fulfill all orders of the Governors of this district of Timor and to maintain and enforce enforce in my kingdom the Catholic faith, to pay the annual tribute when ordered, and to provide auxiliaries in War and support public services when requested to do so. (Boletim 56)

The signing of termos was typically accompanied by the exchange of gifts, that might include a "cane of office," a copy of the document itself, a Portuguese flag, cloth, alcohol and perhaps even guns and gunpowder. These were oaths of fealty and obedience, and as such are part of the feudal Iberian tradition, not a glorious past to which an independent nation might one day trace its founding roots. 


\section{Declaration of the Portuguese Republic}

By the first decade of the twentieth century, Portugal had swapped the inefficient system of vassalage and tribute for one of brutal direct rule that included a head tax and forced labor to fuel the production of coffee. The few voices of open dissent came from the political "deportados" and "degredados" banished from the metropole and other colonies to the furthest reaches of the empire. So when news reached Dili in early October 1910 of the revolution overthrowing the Monarchy and the proclamation of the Portuguese Republic, there was little celebrating. It took three weeks for Governor Alfredo Cardoso Soveral Martins to issue a formal announcement and specific instructions for cosmetic changes in uniforms, letterhead, and so on, and it was not until 5 November that he made a public address. He began:

\section{Meus Senhores:}

Trouxe-nos o telégrafo a notícia da revolta que deu a Portugal um novo regime, satisfazendo os ideais da sua população e abrindo ao seu futuro uma nova era que a todos se impõe como de felicidade e progresso. Leal filha, não podia a colónia de Timor deixar de, com carinhoso entusiasmo, seguir a mãe Pátria, abraçando a Ideia Nova com fé no porvir e arreigada crença num Portugal maior.

Traga o novo regime a felicidade que merece a heróica Nação, cujas tradições enchem de gloriosas páginas a Histtória [sic] do passado e possa a História do futuro registar ainda a grandeza deste povo civilizador e honrado.

Gentlemen:

A telegraph brought us news of the revolt that gave Portugal a new regime, satisfying the ideals of its people and its future by opening a new era for all of happiness and progress. Loyal daughter, the colony of Timor could not but follow, with loving enthusiasm, the mother country, embracing the new idea with faith in the future and enduring belief in a greater Portugal.

The coming of the new regime deserves the happiness that the heroic nation, whose traditions fill the pages of glorious history of the past and the history of the future can still record the greatness, of this civilizing and honorable people. (Oliveira 43) 
Like birthday celebrations for Belgium's King Leopold II in Leopoldville and commemorations of the founding of the Dutch Republic in colonial Batavia, Governor Martins' stern salute to the "happiness and progress" of the mother country made little sense addressed to the people of the "loyal daughter." The abolition of the symbols of monarchy and plans to liquidate the indigenous kingdoms were a direct threat to the Timorese aristocracy. The combination of Republicanism and the announcement of a one hundred and fifty percent increase in the annual head tax was enough to prompt the last great rebellion against Portuguese rule, lasting from late 1911 through 1912. Ironically, the planning is said to have taken place when a number of indigenous rulers and their retinues were in Dili on 5 November 1911 for the first anniversary of the proclamation of the Republic. Scholars have claimed that during the uprising Dom Boaventura da Costa Sotto-Maior of Manufahi "establish[ed] a seat of government" (Hill 46), and it is not uncommon to hear East Timorese today say that Dom Boaventura even proclaimed an independent republic, though there does not appear to be any evidence to support either claim. The rebellion was crushed in due course, at an enormous cost in life and property. Republican sentiment in Timor soon lost its luster and Portuguese officials went on to pen a number of books proclaiming the savagery of the native insurrection. The most delirious of these is Teófilo Duarte’s Timor (Ante-Camara do Inferno?!), the cover of which shows a Timorese warrior holding a severed head.

\section{Declaration of Independence, 1975}

The Armed Forces Movement of April 1974 overthrew five decades of quasifascist rule in the metropole and opened the gates for decolonization of the "overseas provinces." In contrast to the African colonies, where armed struggles for independence had raged for a decade, at the furthest reaches of the empire the small coterie of Portuguese-educated East Timorese rushed to establish political parties for the first time. There were ideological and pragmatic differences, to be sure, but all agreed on the need for decolonization. Indonesian intelligence courted the parties and inflamed their suspicions of one another, eventually resulting in a coup détat by the Timorese Democratic Union (União Democrática Timorense, UDT) in August 1975 and a counterattack by the 
Revolutionary Front for an Independent East Timor (Frente Revolucionária de Timor-Leste Independente, Fretilin). After a brief period of civil conflict, UDT forces retreated across the border into Indonesian West Timor, the Portuguese governor and his staff fled to the offshore island of Atauro, and Fretilin, which continued to recognize Portuguese sovereignty and demand a formal process of decolonization, found itself in the unwanted position of de facto government.

A season of proclamations ensued. On 1 September 1975, two leaders of the União Democrática Timorense (UDT) issued a proclamation on behalf of the people of Bobonaro district, which borders Indonesian West Timor, stating that they had broken all ties with Portugal and demanding Indonesian assistance to free all people of "East Timor" (Integrasi 226). A few days later several leaders of the pro-Indonesian party Apodeti (Associação Popular Democrática Timorense) met in a forest near the town of Suai and issued another "declaration" requesting integration with the Republic of Indonesia (Vieira). And on 7 September, the leaders of UDT, Apodeti, and two minor parties (Kota and Trabalhista) signed a petition addressed to Indonesian President Soeharto asking that Portuguese Timor be integrated into Indonesia (CAVR 44-5). These declarations coincided with a sharp increase in covert Indonesian operations across the border and preparations for a full-scale invasion. Indonesian forces seized border towns and warships in coastal waters shelled Fretilin defenses. And so, on 28 November, in a hastily organized and rather grim affair in Henry the Navigator Square in front of the Pálacio do Governo, the new flag of East Timor was raised and Fretilin President Francisco Xavier do Amaral read the one sentence declaration of independence:

Encarnando a aspiração suprema do povo de Timor-Leste e para salvaguarda dos seus mais legítimos direitos e interesses como nação soberana, o Comité Central da Frente Revolucionária de Timor-Leste Independente - Fretilin - decreta e eu proclamo, unilateralmente, a independência de Timor-Leste que passa a ser, a partir das 00.00 h de hoje, a República Democrática de Timor-Leste, anti-colonialista e anti-imperialista.

Viva a República Democrática de Timor-Leste!

Viva o povo de Timor-Leste livre e independente!

Viva a Fretilin! 
Expressing the highest aspirations of the people of East Timor and to safeguard the most legitimate interests of national sovereignty, the Central Committee of the Revolutionary Front for an Independent East Timor FRETILIN - decrees by proclamation, unilaterally, the independence of East Timor, from 00.00 hours today, declaring the state of the Democratic Republic of East Timor, anti-colonialist and anti-imperialist.

Long live the Democratic Republic of East Timor!

Long live the people of East Timor, free and independent!

Long live FRETILIN! (Joliffe 212)

The declaration was made out of necessity, but it was also inspired by and modeled on the declaration issued two weeks earlier by the Movimento Popular de Libertação de Angola (MPLA) in Luanda establishing the People's Republic of Angola. The language may be militant, but the claims were framed in terms of the international legal discourse of the right to self-determination and state sovereignty.

As was the case in Angola, where a day after the MPLA declaration the Frente Nacional de Libertação de Angola and the União Nacional de Independência Total de Angola issued a rival declaration, the Fretilin proclamation did not go uncontested. On 29 November, the Indonesian Minister of Information released a statement of concern about Fretilin's "unilateral declaration" (CAVR 57). And so, on 29 November, the four parties that had petitioned President Soeharto in September issued what became known as the Balibo declaration. It was issued in both English and Portuguese, though only the original English version is available. The crucial penultimate paragraph reads:

In the name of the All Mighty [sic], and by the reasons previously referred, we do proclaim solemnly the Integnation [sic] of the whole territory of the ex-portuguese colony of Timor with the Indonesian Nation, as this proclamation means the most highly expression of the Portuguese Timor people feelings. (Integrasi 283-4) ${ }^{1}$

The declaration, of course, was no more than window-dressing intended to justify the illegal Indonesian invasion, launched on 7 December 1975, only 
hours after US President Ford and Secretary of State Henry Kissinger met with President Soeharto in Jakarta.

\section{Independence Restored ... and Debated}

After twenty-four years of occupation and terrible human rights abuses, Soeharto's resignation in May 1998 and the demise of his New Order regime opened the way for a final resolution to the East Timor "problem." In 1999, tripartite negotiations between Portugal, which was still recognized in international law as the colonial power, Indonesia and the United Nations led to an agreement to hold a referendum on the future of the territory. The Indonesian military's efforts to terrorize the population into accepting the offer of broad autonomy failed and on 30 August the East Timorese overwhelmingly voted in favor of independence. A further flurry of violence ensued, but Indonesia's parliament eventually agreed to relinquish the territory and the United Nations established a mission to manage the territory and oversee the transition to statehood. ${ }^{2}$

Under the UN mission, security within East Timor was restored, efforts were made to repatriate the huge number of displaced people in West Timor, and reconstruction of infrastructure got underway. In 2001 elections were held for seats in the Constituent Assembly, with Fretilin winning an outright majority. Fretilin was thus in a position to dominate the writing of and debate over a new constitution. One point that leaders across the political spectrum could agree on was that Portuguese and Tetum would become the national languages of the new nation-state. But the final version of the constitution also reflected Fretilin's version of history. The preamble begins:

Following the liberation of the Timorese People from colonization and illegal occupation of the Maubere Motherland by foreign powers, the independence of East Timor, proclaimed on the 28th of November 1975 by the Revolutionary Front for an Independent East Timor (FRETILIN), is recognized internationally on the 20th of May 2002. (RDTL 9)

This point is reiterated in Section 1, paragraph 2 of the Constitution, which states that " $[\mathrm{t}]$ he $28^{\text {th }}$ of November 1975 is the Day of Proclamation of 
Independence of the Democratic Republic of East Timor" (RDTL 11). The $20^{\text {th }}$ of May, therefore, was to mark the restoration of independence proclaimed twenty-seven years before.

On the evening of 20 May 2002, East Timorese dignitaries, UN officials and representatives of nations around the world gathered on a make-shift stage in a dusty field on the western outskirts of Dili. Tens of thousands of people, most arriving on foot, filled the field. Just before midnight, UN Secretary General Kofi Annan took the podium. "This will not be a long speech," he began. "It cannot be. For in just a few minutes, I must stop as we reach midnight on 19 May. With the start of 20 May, you will step into a new era in your history, as an independent nation. I am deeply honoured and moved to be with you at this moment" (United Nations). There was no need for a proclamation: independence had been foretold. As the clock struck midnight, fireworks filled the clear night sky and the people of East Timor celebrated fulfillment of what Nobel laureates Bishop Belo and José Ramos-Horta had once called "the impossible dream" (Kammen 387-9).

But East Timor's declaration of independence has remained a highly emotive issue. Fretilin has argued that the choice of 28 November 1975 was meant to honor the party's historic role and the heroes who had fallen defending the first Democratic Republic. Unstated but of equal importance is that the choice of 28 November highlights the illegality of the 24-year Indonesian occupation. A group calling itself Conselho Popular pela Defesa de República Democrática de Timor-Leste (Popular Council for the Defense of the Democratic Republic of East Timor, abbreviated CPD-RDTL) took the argument a step further, insisting that the new state should be based on the first República Democrática de Timor-Leste - including recognition of 28 November as independence day, the Fretilin flag and anthem, etc. - and demanding that the United Nations leave the territory altogether. Meanwhile, parties that opposed Fretilin's domination of the Constituent Assembly and the transformation of that body into the first parliament, viewed the decision to recognize 28 November 1975 as proclamation day as an attempt to monopolize national symbols and charged that Fretilin was bent on creating an authoritarian state modeled on Mozambique under Frelimo. 
These were not trivial matters. Following the restoration of independence, political tensions rose and the young country was rocked by a series of minor riots in 2002 and 2003. In 2005, a group of young activists (including one of my former students from the Faculty of Social and Political Sciences at the National University of Timor Lorosae) gathered in Fatuberliu, near the south coast, where they declared the establishment of the Republico Timor Tasi Mane - Timorese Republic of the South Sea. Four individuals were charged with committing subversive acts under Article 106 of the Penal Code. In court, the defendants explained that they had declared their own republic because of "social and economic problems" (Judicial System Monitoring Programme). The judge rejected their defense and sentenced two of the men to four years in prison and the other two to two years each. Worse was yet to come. The following year, the politicization of accusations of discrimination within the new Army spiraled out of control, resulting in armed clashes in the capital and displacement of more than 100,000 people from their homes. The conflict was not simply over the fruits of independence, but also the symbols on which that independence stand.

This year (2012) East Timor is due to hold national elections and celebrate three major anniversaries: the $500^{\text {th }}$ anniversary of the arrival of the Portuguese in Timor, the $100^{\text {th }}$ anniversary of Dom Boaventura's uprising, and the $10^{\text {th }}$ anniversary of (the restoration of) independence. In this context, it may be of help to reflect on the history of declarations - both real and imagined - and the responses they have elicited.

\section{Notes}

1 The original text is full of grammatical and spelling errors. For a linguistic analysis of the multiple texts, see Akihisa Matsuno, "The Balibo Declaration."

2 The best account of 1999 is Geoffrey Robinson's "If You Leave Us Here, We Will Die": How Genocide Was Stopped in East Timor. 


\section{Works Cited}

Boletim da Provincia de Macau e Timor. 28.8. 25 February 1882. Print.

Boxer, C.R. Fidalgos in the Far East, 1550-1770. London and New York: Oxford UP, 1968. Print.

CAVR. Chega! The Report of the Commission for Reception, Truth and Reconciliation in TimorLeste. Dili, East Timor: 2005. Print.

Duarte, Teófilo. Timor (Ante-Camara do Inferno?!). Lisbon: Famalição, 1930. Print.

Gunn, Geoffrey C. Timor Loro Sae: 500 Years. Macau: Livros do Oriente, 1999. Print.

Gusmão, Xanana. Timor Lives! Speeches of Freedom and Independence. Alexandria, New South Wales: Longueville Books, 2005. Print

Hägerdal, Hans. Lords of the Land, Lords of the Sea: Conflict and Adaptation in Early Colonial Timor, 1600-1800. Leiden: KITLV Press, 2012. Print.

Hill, Helen. Stirrings of Nationalism in East Timor: Fretilin 1974-1978: The Origins, Ideologies and Strategies of a Nationalist Movement. Otford, New South Wales: Otford Press, 2002. Print. Integrasi: Kebulatan Tekad Rakyat Timor Timur. Jakarta: Yayasan Parikesit, 1976.

Jolliffe, Jill, East Timor: Nationalism and Colonialism. St. Lucia: U of Queensland P, 1978. Print. Judicial System Monitoring Programme. "Summary of Cases before the Courts." No. 18/2005. Web. 28 Feb. 2012.

Kammen, Douglas. "Fragments of Utopia: Popular Yearnings in East Timor." Journal of Southeast Asian Studies 40.2 (June 2009): 385-408. Print.

Maier, Pauline. The Declaration of Independence and the Constitution of the United States. Boston: Massachusetts Historical Society, 1998. Print.

Matos, Artur Teodoro de. Timor Português 1515-1769: Contribuição para a sua História. Lisbon: Faculdade de Letras da Universidade de Lisboa, Instituto Histórico Infante Dom Henrique, 1974. Print.

Matsuno, Akihisa. “The Balibo Declaration." East Timor Documents 36-37 (March 13-June 26, 1995): 12-15. Print.

Oliveira, Luna de. Timor na História de Portugal. Vol. 1-4. Lisbon: Agência Geral do Ultramar, 1949. Print.

RDTL. Constitution of the Democratic Republic of Timor-Leste. 2002. Web. 24 Feb. 2012.

Robinson, Geoffrey. "If You Leave Us Here, We Will Die": How Genocide Was Stopped in East Timor. Princeton: Princeton UP, 2009. Print.

United Nations. "'The United Nations will stay ... your friends will continue to help', says Secretary-General in salute to independent East Timor." Press Release SG/SM/8243. 20 May 2002.Web. 28 Feb. 2012.

Vieira, Cláudio. Personal Interview. 10 June 2004. 
Douglas Kammen is an assistant professor in the Department of Southeast Asian Studies at the National University of Singapore. His research on East Timor includes articles on military aspects of the Indonesian occupation, human rights, and political culture. He can be reached at seadak@nus.edu.sg. 